\title{
PAWs model of Future Customer Behaviour
}

\author{
Anthony Perrone, Central Queensland University, Queensland, \\ Australia
}

\begin{abstract}
Service quality is an area that has been subjected to widespread research. This has included those elements relating to the repurchase intentions of customers. Service performance, in a service setting environment, can have an impact on what a customer experiences, their subsequent behaviour and perceptions. The material in this paper has been extracted from a larger research of an empirical study of five hundred coffee shop patrons. The research conducted measured the effect of service performance on consumer's perceptions of service quality, in a model relating customer service quality with customer behavioural outcomes in a retail service setting. The resulting affect empirically shows that service performance, through the specific grouping of known service quality constructs, improves the prediction of customer post-purchase perceptions and behaviours. However of greater significance in contributing to marketing theory, a general service quality model relating customer service quality with post-purchase customer behaviours, the PAWs model of Future Customer Behaviour was developed, which may be of value to researchers and practitioners alike in studying various service sector organisations.
\end{abstract}

Keywords: Service Quality, Retail, Post-purchase Behaviour, Consumer Behaviour, Service Performance, Services Marketing

\section{Introduction and Purpose}

TN COUNTRIES SUCH as Australia, 85 percent of GDP (Australian Bureau of Statistics 2007 and Veldre 2007), Germany, 72 percent of GDP (CIA World Fact Book 2009), India 56 percent of GDP, (Thaindian News 2009), United Kingdom, 76 percent of GDP (Office of National Statistics 2009) and the United States of America, 83 percent of GNP (Howells \& Barefoot 2007), the service industry's are the largest sectors, fastest growing and one of the dominant drivers of economic growth (Bigné, Moliner \& Sanchz 2003 and Brady, Cronin \& Brand 2002). It is therefore understandable that the services sector has resulted in intense competition between service providers (Brady, Cronin \& Brand 2002), thereby increasing service provider perspectives, understandings and awareness levels from an economic viewpoint of consumer's evaluative processes. The resulting factors then contribute to their profitability and market performance from future customer behaviour (Zeithaml 2000; Rust \& Zahorik 1993 and Koska 1990).

The purpose of this paper is to review how service performance affects customer post purchase behaviour. Specifically, by researching its impact on customer perceptions of service quality through the development and testing of a new theoretical framework by creating a new model on service quality, PAWs model of Future Customer Behaviour. This research conducted addressed how future customer behaviour can influence the way consumers react to a product or service provider, and contributes to our understanding of consumer behaviour (d'Astous 2000). The study also describes the theoretical foundation and the methodology 
proposed on the service environment and how that environment relates to subsequent customer perceptions and behaviours. This new service quality model is apply named after its creator Dr. Anthony Perrone and Associate Professor Antony Ward, long time service quality author and researcher, Perrone and Wards (PAWs) model of Future Customer Behaviour.

This study investigated the service environment, which was empirically tested in a retail setting, coffee shops and provides a greater understanding of consumer's responses to customer post purchase perceptions. From the review of the relating literature and its possible impact on service quality, the outcome, as perceived by customers, identified a gap in existing models on service quality. Therefore the research conducted addressed this gap by developing then testing a new model on service quality by combining seven known service quality constructs; product delivery, functional service quality and servicescapes and their prediction of customer satisfaction, relationship strength, retention intentions and word-of-mouth.

In order to measure how the service environment relates to subsequent customer perceptions and behaviours, the proposed model has three types of variables: service performance, post purchase perceptions and future customer behaviour. The concepts of each variable are provided as follows:

- Customer perceptions of service performance provide service providers with a comprehensive assessment of their business operations, align performance measures, facilitate communication with staff and their customers and provide feedback for training and develop learning (Klenke \& Trickey 2002). The three independent constructs associated with service performance are product delivery (the product), functional service quality (often referred to as customer service) and servicescape service quality;

- Post purchase perceptions indicate how customers reflect service performance in terms of customer satisfaction and their perceived relationship with the service provider. There are two mediating constructs associated with post purchase perceptions, customer satisfaction and relationship strength;

- Future customer behaviour is measured by the intentions of customers' to re-purchase and future word-of-mouth behaviour. Service providers who can predict future purchase behaviour, based on their relationships with their customer's by reducing or eliminating potential negative evaluations of their company, will reduce those customers' intentions to switch resulting in financial gains for their firms (Verhoef 2003). Retention intentions and word-of-mouth communications made up the two dependent future customer behavioural constructs reviewed.

The developed model detailed the relationship between the seven service quality constructs in determining the predictive powers of future customer behaviour by;

- contributing to the marketing literature specifically relating to service quality and customers post purchase behaviours;

- providing a practical element for the services industry with a model relating to improved predictive relationships; and,

- as the review of the literature indicated, empirical evidence is lacking to indicate that the use of the specified constructs are tested in service quality models that seek to predict future customer behaviour. 


\section{Service Quality}

The review of the literature identified the extensive debate associated with service quality due to the varying outcomes as informed in the literature with numerous adaptations to the gap based SERVQUAL (Parasuraman, Zeithaml, \& Berry 1988, 1985) model (Cui, Lewis \& Park 2003; Aldlaigan \& Buttle 2002; Newman 2001; Cronin \& Taylor 1994, 1992; Brown, Churchill, \& Peter 1993; Bitner 1990 and Carmen 1990). The significance of the services industry has resulted in fierce competition among service providers (Brady, Cronin \& Brand 2002). From an economic perspective, a service providers understanding of consumers evaluative processes contributes to their profitability and market performance from future customer behaviour (Zeithaml 2000; Rust \& Zahorik 1993 and Koska 1990). From a social viewpoint, however, service providers have the opportunity to contribute to a consumer's well being as their service is likely to impact on a customer's quality of life (Sirgy 1996 and Sirgy \& Lee 1996).

Service quality has become an increasingly indispensable aspect for service providers in managing a successful business operation in today's competitive service market (Blose, Tankersley \& Flynn 2005 and Schneider, Holcombe \& White 1997), with consumer's perceptions of the actual quality of the customer service delivered and received in relation to the product often influencing a service provider's service quality (Perrone 2009). Consumer reactions to service quality can result in a number of positive benefits, such as:

- $\quad$ higher consumer retention rates;

- attraction of new customers through word-of-mouth referrals;

- successful cross-sell and up-sell opportunities by service providers;

- service provider market share increases;

- improvements in staff morale and productivity;

- a decrease in staff turnover;

- reduction of operating costs; and,

- improved financial performance

(Duncan \& Elliot 2004; Ranaweera \& Neely 2003; Jamal \& Naser 2003; Alexander, Dimitriadis \& Markata 2002; Yavas, Bilgin \& Shemwell 1997; Buttle 1996; Kim \& Kleiner 1996 and Zahorik \& Rust 1992).

Since the 1970's service quality in the retail environment has provided marketers with a vast field of research. Some researchers appear compelled to develop alternative conceptualisations of the construct and to continue to study service quality (Al-Hawari \& Ward 2006; Broderick \& Vachirapornpuk 2002; Soteriou \& Stavrinides 2000; Sweeney, Soutar \& Johnson 1997; Dabholkar 1996; McAlexander, Kaldenberg \& Koenig 1994; Lytle \& Mokwa 1992; Grönroos 1984 and Haywood-Farmer 1988). The review of various service quality models subsequently revealed that service quality outcome and measurement is dependent on the type of retail setting, situation, time, and need factors. In developing this study's model, those models helped in understanding the complexity of service quality.

Additionally, customer's expectations towards particular retail products are ever changing with respect to factors such as; time, increase in the number of encounters with a particular retailer, and the competitive environment (Guru, 2003; Sureshchander, Rajendran \& Anatharaman 2002; Silvestro \& Cross 2000; Lasser, Manolis, \& Winsor 2000; Gummesson, 
1998; Chang \& Chen, 1998; Hallowell, 1996; Gammie, 1992; Cronin \& Taylor, 1992 and Leonard \& Sasser 1982). Therefore marketers have been continually exploring ways and means of producing a coherent framework for analysing retail environments (Gilboa \& Rafaeli 2003).

The purpose of this research was to develop and define such an alternative model. The proposed conceptualisation therefore draws on existing literature to develop a theory, which represents a fusion of the current literatures. One reoccurring theme that continued to emerge from the literature was the conceptualisation of service quality from a consumer's perception of two construct outcomes, product delivery and customer service (functional service quality Grönroos 1990, 1982). This interaction is a critical part of the overall service product delivery and essential to customers' perception of service quality (Perrone \& Ward 2006).

The combining of those two constructs and the addition of the servicescape construct provided an informed measure of service performance in developing a new proposed service quality model, PAWs Model of Future Customer Behaviour. Figures 1 and 2 shows the illustrated and structural model of future customer behaviour as developed for this study.

\section{Service Performance Post Purchase Perceptions Future Customer Behaviour}

Product Delivery (PD)

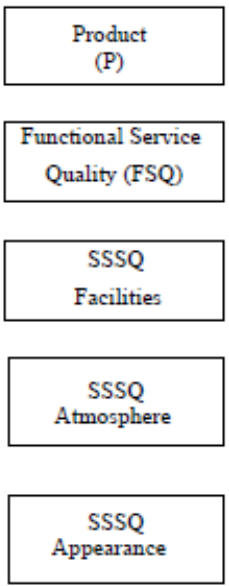

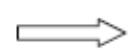

Retention Intentions (RI)

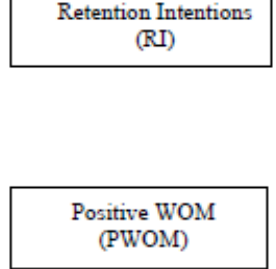

Figure 1: PAWs Illustrated Model of Future Customer Behaviour 


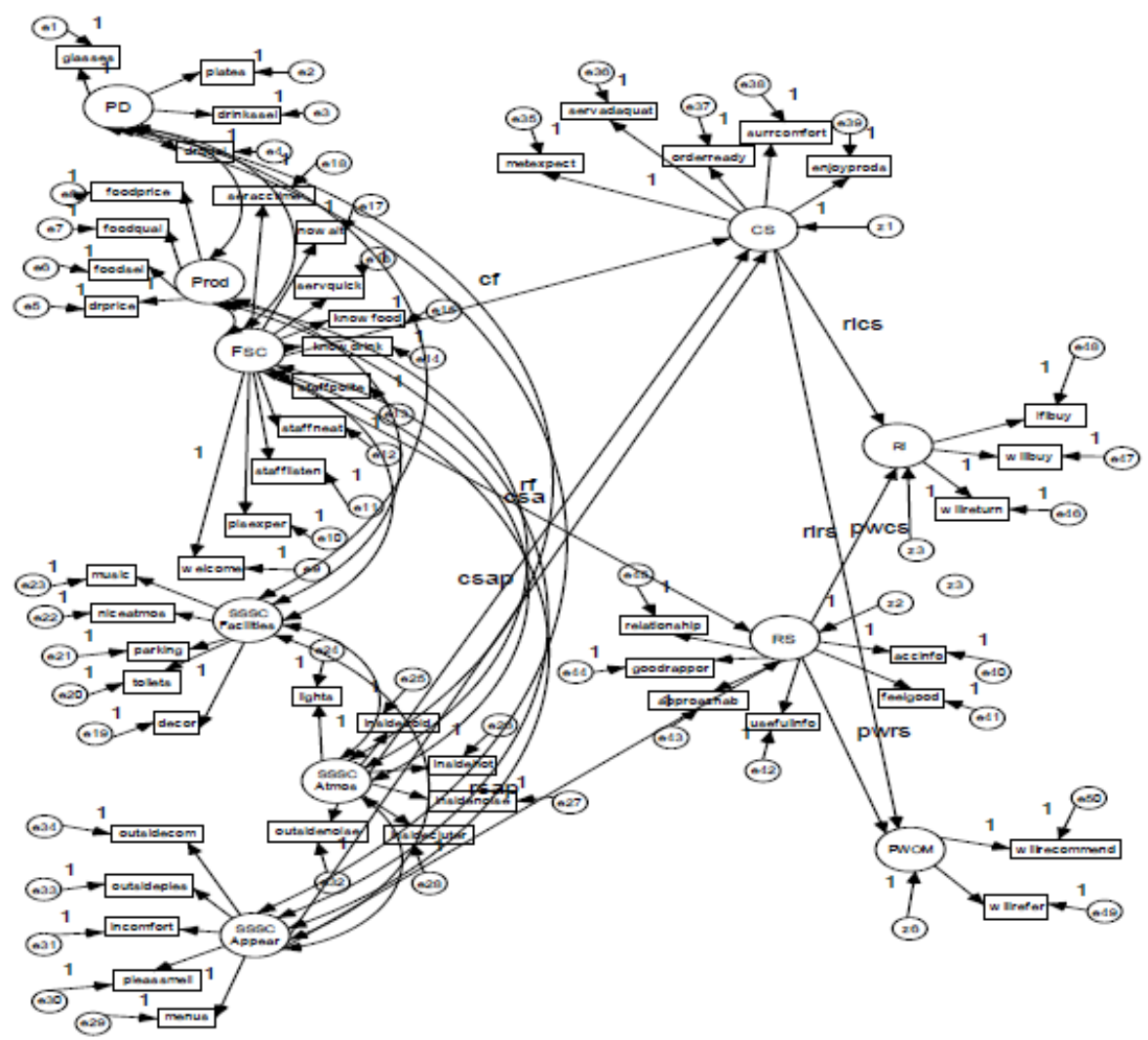

Figure 2: PAWs Structural Model of Future Customer Behaviour

From the literature and the model as presented in Figures 1 and 2, one hypothesis was developed: H1 - How does service performance relate to customer's post purchase perceptions and future behaviour?

\section{Method}

A test instrument was developed for administration to patrons of coffee shops by trained researchers. A total of 500 completed surveys were obtained from a random sample of participants who were surveyed at ten different coffee shop locations. The test instrument used multi-attribute measures, with each of the individual antecedents measured using a seven point agree/disagree scale, that is, of the three independent variables, 8 items for product delivery, 10 items for functional service quality and 16 items for servicescape service quality. For the mediating variables, 5 items were used to measure customer satisfaction and 6 items to measure relationship strength. The dependent variables of retention intentions used 3 items while word-of-mouth used 5 items. The scales developed for this study employed exploratory and descriptive research design methods in a two stage process with Stage 1 (exploratory), utilising focus groups and personal interviews, and Stage 2 (descriptive), using 
quantitative methods for the main data gathering by administering a structured self administered survey. The purpose of Stage 1 was to inform the construction of the test instrument for Stage 2 (Kvale, 1996; Thompson, Locander \& Pollio 1989 and Hudson \& Ozanne, 1988).

\section{Results}

During data analysis descriptive statistics, Exploratory Factor Analysis (EFA) and Confirmatory Factor Analysis (CFA) were conducted. EFA and CFA are considered preliminary processes prior to analysing research data using Structural Equation Modelling (SEM). As a first step descriptive analysis was performed using the Statistical Package for the Social Sciences software (SPSS), which prepared the data providing details describing a set of factors for this study (Sekaran 2003). EFA followed the SPSS process leading onto the assessment of the measurement model using CFA. The final step was the hypotheses testing of the relationships using SEM, which was conducted using AMOS software. Pre-analytical process of the data preparation ensured the data were complete and accurate by coding, transcribing or the entering of the data into a computer database and accounting for missing responses to further ensure the results could be meaningfully interpreted from the data (Trochim 2003 and Malhotra 1999). Various tests were conducted including eliminating tests for outliers, descriptive statistics of demographic variables, undertaking data transformation and ensuring scale validity and reliability were additionally explored to ascertain a better representation of the data (Sekaran 2003).

The model gave a highly significant result for both goodness-of- fit and $\mathrm{R}^{2}$ value. Table 1 provides statistics for nine fit indices when combined provided overall representation of the compatibility between the data and the model. The $\mathrm{R}^{2}$ informs how much of the variance in a dependent construct is explained by the representative model. Those explained variances are expressed in the form of percentages (Pallant 2005). Thus H1 is supported and was significant at the $\mathrm{p}=0.000$ level.

Table 1: Goodness-of-fit and $\mathrm{R}^{2}$ for the model of Future Customer Behaviour

\begin{tabular}{|c|c|c|c|}
\hline \multicolumn{2}{|c|}{ Goodness-of-fit indices } & \multicolumn{2}{|c|}{$\mathrm{R}^{2}$ Constructs } \\
\hline CMIN/DF & 2.54 & RS & 0.642 \\
\hline RMSEA & 0.072 & CS & 0.719 \\
\hline GFI & 0.71 & RI & 0.651 \\
\hline CFI & 0.85 & PWOM & 0.433 \\
\hline NFI & 0.77 & & \\
\hline TLI & 0.84 & & \\
\hline Chi-square & 28.80 & & \\
\hline PNFI & 0.71 & & \\
\hline AIC & 3168.564 & & \\
\hline \multicolumn{2}{|c|}{$\begin{array}{l}\text { Source: Developed for } \\
\text { this study. }\end{array}$} & & \\
\hline
\end{tabular}




\section{Discussion}

The results show that PAWs model of Future Customer Behaviour gives an excellent relationship between the service performance constructs and the post purchase perceptions and future behaviour constructs (adjusted $\mathrm{R}^{2}=\mathrm{RS} 0.642$, CS 0.719, RI 0.651 and PWOM 0.433). This result gives a strong indication that PAWs model of Future Customer Behaviour in a retail service setting of a coffee shop was an acceptable model and would therefore be a reliable model to use in the testing of other retail service settings. Thus, H1 is supported in this context.

This research is limited by being a single test in a single service setting. In order to generalise the results a large number of such comparisons will need to be conducted in a number of service settings and industries. While there is face validity in supporting H1 in a retail setting, this validity may not be able to be supported in other service settings, such as hospitality, banking, etc. Thus, for future research there is a need for testing in a number of service settings to establish those cases where the service performance variable is significant and those where it may not be significant, and also to establish how the size of effect varies in different situations.

This research is of much importance for the service industry as the significance and size of effect on customer perceptions and future behaviours of service quality of the service performance constructs has had little empirical testing. As no models were identified that used the service performance independent constructs in the particular grouping with the other service quality constructs. Therefore, this study has distinguished this model from those presented in studies previously and ultimately playing, as a collective, a significant role in the development of service quality perceptions as they are presented in this research and thereby clearly having a significant effect on the customers overall perception and behaviours.

\section{References}

Aldlaigan, A \& Buttle, F 2002, 'SYSTRA-SQ: a new measure of bank service quality', International Journal of Service Industry Management, vol. 13, no. 4, pp. 362-81.

Alexandris, K, Dimitriadis, N \& Markata, D 2002, 'Can perceptions of service quality predict behavioural intentions?: an exploratory study in the hotel sector in Greece', Managing Service Quality, vol. 12, no. 4, pp. 224-31.

Al-Hawari, M \& Ward, T 2006, 'The effect of automated service quality on Australian banks' financial performance and the mediated role of customer satisfaction', Market Intelligence and Planning, vol. 24, no. 2, pp. 127-47.

Australian Bureau of Statistics (ABS) 2007, Australian system of national accounts; labour force Australia (detailed), Australian Bureau of Statistics, viewed 5 July 2007, www.aph.gov.au/house/committee/efpa/services/report.htm

Bigne, E, Moliner, M \& Sanchz, J 2003, 'Satisfaction in multiservice organizations: the case of Spanish public services', Journal of Service Marketing, vol. 17, no. 4, pp. 420-42.

Bitner, M 1990, 'Evaluating service encounters: the effects of physical surroundings and employee responses', Journal of Marketing, vol. 54, no. 4, pp. 69-82.

Blose, J, Tankersley, W \& Flynn, L 2005, 'Managing service quality using data envelopment analysis', The Quality Management Journal, vol. 12, no. 2, p. 7.

Brady, M, Cronin, J \& Brand, R 2002, 'Performance-only measurement of service quality: a replication and extension', Journal of Business Research vol. 55, no. 1, pp. 17-31. 


\section{THE INTERNATIONAL JOURNAL OF KNOWLEDGE, CULTURE AND CHANGE MANAGEMENT}

Broderick, A \& Vachirapornpuk, S 2002, 'Service quality in internet banking: the importance of customer role', Marketing Intelligence \& Planning, vol. 20, no. 6, pp. 327-35.

Brown, T, Churchill, G \& Peter, P 1993, 'Research note: improving the measurement of service', Journal of Retailing of Consumer Services, vol. 69, no. 1, pp. 127-39.

Buttle, F 1996, 'SERVQUAL: Review, critique, research agenda', European Journal of Marketing, vol. 30, no. 1, pp. 8-32.

Carman, J 1990, 'Consumer perceptions of service quality: an assessment of the SERVQUAL dimensions', Journal of Retailing of Consumer Services, vol. 66, pp. 33-55.

Chang, T \& Chen, S 1998, 'Market orientation, service quality and business profitability: a conceptual model and empirical evidence', Journal of Services Marketing, vol. 12, no. 4, pp. 246-64.

CIA World Fact Book, Germany 2008, viewed February 2009, https://www.cia.gov/library/publications/the-world-factbook/geos/gm.html.

Cronin, J \& Taylor, S 1992, 'Measuring service quality: a re-examination and extension', Journal of Marketing, vol. 56, no. 3, pp. 55-68.

Cronin, J \& Taylor, S 1994, 'SERVPERF versus SERVQUAL; Reconciling performance-based and performance-minus-expectations measurement of service quality.' Journal of Marketing vol. 58, no. 1, pp. 125-31.

Cui, C, Lewis, B \& Park, W 2003, 'Service quality measurement in the banking sector in South Korea ', The International Journal of Bank Marketing, vol. 21, no. 5, pp. 191-201.

d'Astous, A 2000, 'Irritating aspects of the shopping environment', Journal of Business Research, vol. 49 , no. 2, pp. 149-56.

Dabholkar, P 1996, 'Consumer evaluations of new technology-based self-service operations: an investigation of alternative models', International Journal of Research in Marketing, vol. 13, no. 1, pp. 29-51.

Duncan, E \& Elliott, G 2004, 'Efficiency, customer service and financial performance among Australian financial institutions', The International Journal of Bank Marketing, vol. 22, no. 5, pp. 319-42.

Gammie, A 1992, 'Stop at nothing in the search for quality', Human Resources, vol. 5, Spring, pp. $35-8$.

Gilboa, S \& Rafaeli, A 2003, 'Store environment, emotions and approach behaviour: applying environmental aesthetics to retailing', International Review of Retail Distribution and Consumer Research, vol. 13, no. 2, pp. 195-211.

Grönroos, C 1982, 'An applied service marketing theory', European Journal of Marketing, vol. 16, no. 7, pp. 30-41.

Grönroos, C 1984, 'A service quality model and its marketing implications', European Journal of Marketing, vol. 18, pp. 36-44.

Grönroos, C 1990, Service management and marketing, Lexington Books, San Francisco, CA.

Guru, C 2003, 'Tailoring e-service quality through CRM', Managing Service Quality, vol. 13, no. 6, pp. 520-31.

Gummesson, E 1998, 'Productivity, quality and relationship marketing in service operations', International Journal of Contemporary Hospitality Management, vol. 10, no. 1, pp. 4-15.

Hallowell, R 1996, 'The relationship of customer satisfaction, customer loyalty, and profitability: an empirical study', The international Journal of Service Industry Management, vol. 7, no. 4, pp. 27-42.

Haywood-Farmer, J 1988, 'A conceptual model of service quality', International Journal of Operations \& Production Management, vol. 8, no. 6, pp. 19-29.

Howells, T \& Barefoot, K 2007, 'Annual industry accounts: advance estimates for 2006', US Bureau of Statistics, May, pp. 12-25.

Hudson, L \& Ozanne, J 1988, 'Alternative ways of seeking knowledge in consumer research', Journal of Consumer Research, vol. 14, no. 4, pp. 508-21. 
Jamal, A \& Naser, K 2003, Factors influencing customer satisfaction in the retail banking sector in Pakistan, International Journal of Commerce \& Management, vol. 13, no. 2, pp. 29-53.

Kim, S \& Kleiner, B 1996, 'Service excellence in the banking industry', Managing Service Quality, vol. 6 , no. 1 , pp. $22-7$.

Klenke, M \& Trickey, P 2002, 'Super balance', Operations and Fulfillment, Nov., 1.

Koska, M 1990, 'High quality care and hospital profits: is there a link?' Hospitals, March, pp. 62-3.

Kvale, S 1996, Interviews an introduction to qualitative research interviewing, Sage Publications, Inc, Thousand Oaks, California.

Lasser, W, Manolis, C \& Winsor, R 2000, 'Service quality perspectives and satisfaction in private banking', Journal of Services Marketing, vol. 14, no. 3, pp. 244-71.

Leonard, F \& Sasser, W 1982, 'The incline of quality', Harvard Business Review, vol. 60, no. 5, pp. 163-71.

Lytle, R \& Mokwa, M 1992, 'Evaluating health care quality: the moderating role of outcomes', Journal of Health Care Marketing, vol. 12, no. 1, pp. 4-14.

Malhotra, N 1999, Marketing research: an applied orientation, Prentice Hall, Upper Saddle River, New Jersey.

McAlexander, J, Kaldenberg, D \& Koenig, H 1994, 'Service quality measurement: examinations of dental practices sheds more light on the relationship between service quality, satisfaction and purchase intentions in a health care setting.' Journal of Health Care Marketing, vol. 14, no. 3, pp. 34-41.

Newman, K 2001, 'Interrogating SERVQUAL: a critical assessment of service quality measurement in a high street retail bank', The International Journal of Bank Marketing, vol. 19, no. 3, pp. 126-39.

Office of National Statistics, UK 2009, viewed December 2009, http://www.statistics.gov.uk/hub/economy/index.html

Pallant, J 2005, SPSS survival manual: a step by step guide to data analysis using SPSS, 2nd edn, Allen \& Unwin, Crows Nest.

Parasuraman, A, Zeithaml, V \& Berry, L 1985, 'A conceptual model of service quality and its implications for future research', Journal of Marketing, vol. 49, pp. 41-50.

Parasuraman, A, Zeithaml, V \& Berry, L 1988, 'SERVQUAL: a multiple-item scale for measuring consumer perceptions of service quality', Journal of Retailing, vol. 64, pp. 12-40.

Perrone, A \& Ward, T 2006, Enhancing the Gronroos model of service quality, paper presented to ANZMAC, Brisbane, Queensland, Australia, December.

Perrone, A 2009, 'How Servicescape Enhances Service Quality', The International Journal of Knowledge, Culture \& Change Management, vol. 9, no. 2, pp. 103-110.

Ranaweera, C \& Neely, A 2003, 'Some moderating effect on the service quality-customer retention link', International Journal of Operation \& Production Management, vol. 23, no. 2, pp. 230-48.

Rust, R \& Zahorik, A 1993, 'Customer satisfaction, customer retention and market share', Journal of Retailing, vol. 69, no. 2, pp. 193-215.

Schneider, B, Holcombe, K \& White, S 1997, 'Lessons learned about service quality: what it is, how to manage it and how to become a service quality organization', Consulting Psychology Journal, vol. 49, no. 1, pp. 35-50.

Sekaran, U 2003, Research methods for business: a skill building approach, 4th edn, John Wiley, New York.

Silvestro, R \& Cross, S 2000, 'Applying service profit chain in a retail environment', International Journal of Service Industry Management, vol. 11, no. 3, pp. 244-68.

Sirgy, J \& Lee, D 1996, 'Setting socially responsible marketing objectives: a quality-of-life approach ', European Journal of Marketing, vol. 30, no. 5, pp. 20-36.

Sirgy, J 1996, 'Strategic marketing planning guided by the quality-of-life (QOL) concept', Journal of Business Ethics, vol. 15, no. 3, pp. 241-59. 
Soteriou, A \& Stavrinides, Y 2000, 'An internal customer service quality data envelope analysis model for bank branches', International Journal of Bank Marketing, vol.18, no. 5, pp. 246-52.

Sureshchander, G, Rajendran, C \& Anatharaman, R 2002, 'The relationship between service quality and customer satisfaction: a factor specific approach', Journal of Services Marketing, vol. 16 , no. 4 , pp. 363-79.

Sweeney, J, Soutar, G \& Johnson, L 1997, 'Retail service quality and perceived value', Journal of Consumer Services, vol. 4, no. 1, pp. 39-48.

Thaindian News 2009, viewed June 19th, http://www.thaindian.com/newsportal/ business/servicesector-contributed-56-percent-to-gdp_100207053.html.

Thompson, C, Locander, W \& Pollio, H 1989, 'Putting consumer experience back into consumer research: the philosophy and method of existential-phenomenology', Journal of Consumer Research, vol. 16, no. 2, pp. 133-46.

Trochim, W 2003, Research methods knowledge base, viewed August 28, 2007 www.trochim.cornell.edu

Veldre, R 2007, Notes on the professional services sector, Department of Industry July 5.

Verhof, P 2003, 'Combining revealed and stated preferences to forecast customer behaviour: three case studies', International Journal of Market Research, vol. 45, no. 4, pp. 467-76.

Yavas, U, Bilgin, Z \& Shemwell, D 1997, 'Service quality in the banking sector in an emerging economy: a consumer survey', The International Journal of Bank Marketing, vol. 15, no. 6, pp. $217-23$.

Zahorik, A \& Rust, R 1992, 'Modelling the impact of service quality of profitability: a review', in T Swartz (ed.), Advances in service marketing and management, JAI Press, Greenwich, CT, pp. 49-64.

Zeithaml, V 2000, 'Service quality, profitability, and the economic worth of customers: what we know and what we need to learn', Journal of the Academy of Marketing Science, vol. 28, no. 1, pp. 67-85.

\section{About the Author}

\section{Dr. Anthony Perrone}

Course Coordinator and Lecturer in Marketing. Currently teaching undergraduate courses in Customer Relationship Marketing, Promotions Management, Marketing and post graduate courses in Integrated Marketing Communications. Developed and designed marketing courses on: principles of marketing, consumer behaviour, selling process and entrepreneurship. Upcoming text inclusions; International Marketing Fifth Edition by Fletcher \& Brown: 'Bringing Australian Fashions to the Singapore Turf Club' case study. Consumer Behaviour Fifth Edition by Schiffman, Ward, Bednall, O'Cass \& Paladino: 'Consumers Decision Making Process: Why buy a frozen Burrito?' case study. Marketing: Real People, Real Choices Second Edition by Solomon, Hughes, Chitty, Fripp, Marshall, \& Stuart: 'Real People, Real Choices' profile feature. Marketing: Real People, Real Choices Second Edition by Solomon, Hughes, Chitty, Fripp, Marshall, \& Stuart: two (2) featured case study reviews. Services Marketing Fifth Edition by Lovelock \& Patterson: Target Marketing: 'Selling Mexican Food to Australians' case study (on-line text resources). Principles of Marketing, Fifth Edition by Kotler: Marketing: Creating Excitement and Value: two (2) featured case studies. Text reviewer for; Marketing Second Edition by Lamb, Hair, McDaniel, Summers\& Gardiner. Advertising and Promotion Second Edition by Belch, Belch, Kerr \& Powell. How to Create an IMC Plan Third Edition by Waller. Principles of Marketing Fifth Edition by Kotler. Former executive manager for Fred Hayman the creator of Giorgio Beverly Hills(VP), 
Neiman Marcus(USA) and David Jones (Australia). Interests include playing tennis, yoga, biking, the beach, camping, and helping and healing those in need. 
